\title{
Student Perceptions of Problem-Based Learning: A Case Study of Undergraduate Applied Agrometeorology
}

\author{
Linda De Wet ${ }^{1}$ and Sue Walker ${ }^{2}$ \\ ${ }^{1}$ Department of Soil, Crop and Climate Sciences, University of the Free State, Agriculture Bldg, 2nd Floor, Office 1.230, \\ Bloemfontein 9301, South Africa \\ ${ }^{2}$ Crops for the Future Research Centre (CFFRC) Level 2 Block B. The University of Nottingham Malaysia Campus Jalan Broga, \\ 43500 Semenyih, Selangor Darul Ehsan, Malaysia
}

Correspondence should be addressed to Linda De Wet; dewetl@ufs.ac.za

Received 27 February 2013; Accepted 25 March 2013

Academic Editors: S. P. Heyneman, V. Kann, and S. Lunsford

Copyright (C 2013 L. De Wet and S. Walker. This is an open access article distributed under the Creative Commons Attribution License, which permits unrestricted use, distribution, and reproduction in any medium, provided the original work is properly cited.

\begin{abstract}
Many students do not seem to transfer their learning during formal education into applications in the real world. The objective of this ongoing study was to investigate the opinion of third-year students concerning their program through problem-based learning and to improve the module where necessary. Students attending theory classes had to apply their newly gained knowledge coupled with real-life weather data to solve a problem during practicums. Students attending practicums were given the same questionnaire thrice; thus, the answers were based on different sets of exercises. Responses by attendees for the three questionnaires were $73 \%$, $100 \%$, and $61 \%$, respectively. Students preferred problem-based practicums (78\%, $54 \%$, and $72 \%$, resp.) to other non-problem-based practicums. Most students thought that their knowledge had improved and it had prepared them better for the workplace (85\%, $77 \%$, and $92 \%$, resp.). Generally students preferred working in groups (74\%, $62 \%$, and $56 \%$, resp.), in contrast to those preferring to work individually. Students benefited from problem-based learning in that they thought they had improved their knowledge, skills, and critical thinking abilities and felt that they had learnt things that they could carry into their future lives out in the world at large and the workplace.
\end{abstract}

\section{Introduction}

Traditional methods of teaching and learning have been used for centuries in almost all countries of the world and are therefore a universal phenomenon [1]. According to Kelly and Finlayson [2], teaching the traditional way is a teacher-centred approach where students follow a strict set of instructions, with perhaps little understanding of the purpose thereof, and in the case of practicums, many students are not able to produce satisfactory interpretation of the observations or results. According to Kendal-Wright and Kusuya [3], this "one-way communication" method of teaching has often been challenged and is not popular because students are passive learners. Using the problem-based approach, however, the emphasis is on students learning something they can apply outside the classroom and not on the teacher merely giving information [4] that the student does not even remember.
Problem-based learning was originally developed medical staff at McMaster University in Canada in the 1970s, and since then many others in different fields have based their own curriculum development on this model [5]. According to Dochy et al. [6], problem-based learning was developed in order to help students in the development of professional skills such as problem-solving, analysis, synthesis, and evaluation, as well as the ability to solve problems in the real world.

According to Kendal-Wright and Kasuya [3], problembased learning starts out with a problem scenario, which requires that a number of learning topics be identified and that the student revisits the material acquired until it has been mastered. Problem-solving skills are therefore developed during the problem-based learning process [3], but one of the goals of problem-based learning is to allow several and not only one single solution [7]. Students actively participate, while identifying learning gaps, researching new knowledge, 
and devising plans and their own success. Students therefore learn independently, as well as from others in their group [7].

Problem-based learning has various advantages and disadvantages. Strohfeldt and Grant [8] list some of the advantages as follows.

(1) The student learns in a more natural way.

(2) Critical thinking is encouraged.

(3) A good relationship between student and facilitator is encouraged.

(4) The student spends on average five to eight hours in preparation for each session, whereas no preparation is done for traditional lectures [8].

Some of the disadvantages are, however, as follows [8].

(1) Staff costs are high as problem-based learning is a staff-intensive process.

(2) High staff workload, especially for initial preparation of new classes.

(3) Facilitator expertise may vary, perhaps resulting in lack of high quality facilitation for all problem-based classes.

Strohfeldt and Grant [8] mention that students often complain of high workloads, but deep learning is best embedded in this way. According to Rust [9] and Biggs [10] students commonly approach learning in one of two ways, that is, a surface or a deep approach. With the surface approach students memorize isolated facts [9]. Students following the deep approach feel the need to engage on a deeper level, trying to understand the bigger picture but in the process also learning more detailed facts. Greasley and Ashworth [11] and Richardson [12] agree that a deep approach to learning includes reading for meaning and understanding. Richardson [12] however, states that there are three approaches to learning: surface approach to memorize for assessment; strategic approach based on obtaining highest marks; and deep approach based on understanding.

According to Strohfeldt and Grant [8], their way of presenting the problem-based learning course addresses one of the greatest problems, that is, high workload for staff, but each institution is free to adapt the model according to their specific needs. Students who normally study alone appreciate the help from group members. Students also learn not to cram, and at-risk students are the ones who mostly benefit [3]. Other authors, such as Zingone et al. [13], also promote mixed active learning (both individual and groups), besides team-based learning in groups.

In the Faculty of Natural and Agricultural Sciences [14] of the University of the Free State (UFS), Bloemfontein, South Africa, there are two streams of undergraduate programs; one of the streams falls under natural sciences and the other under agriculture. One of the syllabi under agriculture is agrometeorology wherein the module LWR314, called "The Influence of Climate on Agricultural Practices," is presented. UFS is also the only university in South Africa that offers a degree in agrometeorology to undergraduate students (Lomas et al. [15]; Lomas et al. [16]). In 2003 the LWR314 was redeveloped as a problem-based learning module by the subject head of agrometeorology to help students develop their professional skills and to expose them to problemsolving skills, which they could use not only in the classroom but in the real world as well. In order to improve the module it was decided to investigate student perceptions of the problem-based module, and so a simple questionnaire was developed in which students could voice their opinions thrice during the semester. Various other studies $[6,17,18]$ used a 4- or 5-point Likert scale as, measuring instrument handed out at the end of the semester, but the questionnaire used in this study made use of a descriptive research analysis approach [19] as the research was aimed at looking at the progress of students throughout the semester. The objective of this study was to investigate the perceptions of students with regard to problem-based learning in the undergraduate applied agrometeorology class and to use the information on their views to further improve the module.

\section{Methodology}

The questionnaire, a one-page sheet consisting of eight questions, was voluntarily and anonymously answered three times during the semester, observing suggestions by Babbie [20]. Mouton [21] also states that sensitive or threatening questions could result in nonresponse or refusal to participate. During 2011, third-year students attending the LWR314 practicum class were each given the questionnaire at three of the thirteen practicum sessions. The first questionnaire was given on 18 March, the second on 6 May, and the last one on 13 May. The same questionnaire was used although the students' answers would be based on different sets of practicum exercises. These were, for the sake of simplicity named P1 (first survey date), P2 (second survey date), and P3 (third survey date). Responses to the first questionnaire (P1) were based on the foregoing seven practicum topics: discomfort indices, short-term weather forecasting, weather and remote sensing, evapotranspiration methods, calculation of heat and cold units, pests and diseases, and frost occurrence along a transect. Responses to the second questionnaire (P2) were based on the following three practicum topics: microclimate manipulation, irrigation scheduling, and fire indices. Responses to the third and final questionnaire (P3) were based on the last three practicum topics: drought mitigation, seasonal forecasting, and wind chill indices. There were three main lecturers presenting the practicums, with two guest lecturers who each presented one practicum exercise, both in the second group.

Figure 1 shows the questionnaire given to students in 2011. Analysis of the answers varied; for example, questions 1 and 2 were straightforward "Yes" $(\mathrm{Y})$ or "No" $(\mathrm{N})$ answers, but the rest of the questions involved some explanation or comment. The straightforward questions, including the instances where students did not answer (indicated by "None"), were summarised descriptively using frequencies and percentages. Similar explanations/comments were grouped together [19] and analysed within and between the questionnaires. Comments which were not repeated were not included, but 
LWR314

The influence of climate on agricultural practices

Practicals (drought, seasonal forecasting, windchill)

Please take a few minutes to answer the following questions honestly. We need your input so that we can improve on the classes and practicals.

Please cross the appropriate box and write answers on the dotted lines.

.000000000

(1) Could you easily access the excel data on blackboard?
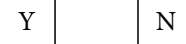

(2) Did you read the instructions for the practical before you attempted to do it?

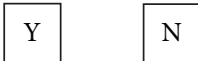

(3) Did you work in a group or individually or both?

Which do you prefer?....................Why?

(4) What is the most important thing/lesson you have learnt from this practical?

(5) Do you feel that you benefited from the practical?

How?

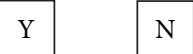

$\mathrm{N}$

(6) Do you prefer this type of (problem-based) practical to practicals which are not problem based?

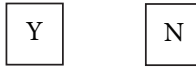

Why?

(7) Do you think the practical has improved your knowledge and better prepared you for the work place?

Why?

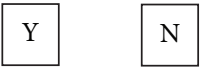

(8) Do you have recommendations for improving the practical? give your

reasons

Thank you for your time and effort!

FIgURE 1: Survey questionnaire given to third-year students at the University of the Free State (2011).

reference to some of them was made in the discussion of results. Two of the questions, that is, questions 3 and 6 , were compared to each other to determine whether a specific method of working was more prevalent under those who preferred problem-based learning. Question 3 asked which method of working (individual, group, or both) students preferred and question 6 asked if students preferred problembased learning to non-problem-based learning. An ANOVA analysis was done to test whether there were significant differences $(P<0.05)$ between the survey dates $(\mathrm{P} 1, \mathrm{P} 2$, and P3) for percentages of all yes and no questions (questions 1 , 2, 5, 6, 7 and 8). The null hypothesis was assumed; that is, 
there were no significant differences between the three survey dates.

\section{Results and Discussion}

Forty-one students were registered for the LWR314 module during the first semester of 2011. Of these, 27 of the 37 students who attended (according to signed roll call) completed the P1 questionnaire. The response was thus $73 \%$ of attendees and $66 \%$ of the total number of registered students. Twenty-six students completed the P2 questionnaire although only 22 students attended the practicum (four students completed the questionnaire outside of the practicum time as they were unable to attend this particular practicum session). The response was $100 \%$ for attendees and $63 \%$ for the total number of registered students. Questionnaire P3 was not handed out during the practicum session, as was the case with $\mathrm{P} 1$ and P2, but was completed by students who came to collect their semester test results a few days later. The P3 questionnaire response was $61 \%$ of the total number of registered students.

3.1. Answers to Yes/No Questions. The analyses of yes/no questions for P1, P2, and P3 are given in Table 1. The majority of answers from question 1 asking if students could easily access the Excel data on Blackboard were in the affirmative, with high percentages of 70\% (P1), 85\% (P2), and 96\% (P3) answering yes. Therefore, this shows that as the semester progressed the students became more familiar with accessing data from Blackboard and it could also be interpreted that the students had acquired the necessary skills for using a spreadsheet for this type of problem-based exercise. In contrast the "no" decreased so that all except one student was familiar with this process by the end of the semester.

Results for question 2, which asked if the instructions were read before the practicum was attempted, also indicated $100 \%$ yes answers for P1 and P2, but in P3 one student said no and another did not answer the question (Table 1). Possible reasons for students not answering these first two questions could have originated from the fact that they read the questionnaire hastily instead of slowly and thoroughly. This phenomenon is often observed in students who feel they have too much to do with too little time, and this is in accordance with findings by Strohfeldt and Grant [8].

Question 5, which asked if students felt that they had benefited from the practicums, showed yes results to be in the majority, with $81 \%$ in $\mathrm{P} 1,85 \%$ in $\mathrm{P} 2$, and $84 \%$ in P3 (Table 1). The mean of students who felt they did not benefit was $14 \%$, and probably they were disinterested in this particular subject matter. Only one student in each of P1 and P2 did not answer the question. Perhaps this question was only seen by the student to mean "benefit" in this module, whereas actually one would hope that at least some of the students had learnt some transferable skills that would benefit them in other modules or areas of their lives. According to Forsythe [4], transferable skills include time management, team work, independent learning, decision taking, problem solving, and communicating ideas, in other words, things that would be applicable to other areas in life and not only in the sphere of academics.

Question 6 asked if students preferred these practicum types to non-problem-based practicums, and results once again indicated that the majority of students answered in the affirmative (78\% (P1), 54\% (P2) and 72\% (P3)) (Table 1). It is probably important for lecturers in other courses to take note of this result, that students feel that they learnt more from "problem-based" classes and to try to include such studies into their classes also. An average of 30\% said they did not prefer the problem-based practicum, and 1 or 2 students preferred to give no answer to the question at all. The low result of $54 \%$ for the middle survey date at P2 may have something to do with (a) the fact that classes were presented by guest lecturers during the time that the $\mathrm{P} 2$ questionnaire was given; (b) the midterm tests; and (c) the lower number of students who actually attended that specific practicum class.

Question 7 asked if students thought that their knowledge had improved and better prepared them for the workplace (Table 1). Most of the students felt that this was the case (85\% (P1), 77\% (P2) and 92\% (P3)), while 15\%, 19\%, and 8\%, respectively, felt that it was not the case. Only 1 student from P2 did not answer this question. Of course these answers are only subjective as these students have not yet entered the workplace as such, because they have not yet finished their full-time studies or graduated.

Lastly, question 8 asked if there were any recommendations for improving the practicums (Table 1). Students who said no were $30 \%(\mathrm{P} 1), 23 \%(\mathrm{P} 2)$, and $20 \%(\mathrm{P} 3)$, respectively, while $30 \%, 27 \%$, and $24 \%$ did not answer the question. It was surprising that this is the only question where the "no" and "none" responses have similar numbers of students, almost as if some $30 \%$ of the students do not want to participate in the formulation of the course or they feel that is not their responsibility, and so they show disinterest by not even responding to this question. Despite this, the highest response to question 8 is still with the students answering a "yes" indicated by $41 \%, 50 \%$, and $56 \%$, respectively (Table 1). It is also interesting that this proportion of the class increased as the semester progressed, and this shows that although the majority agreed that the method of learning and teaching is good, they still have helpful suggestions to improve the class further.

3.2. Answers to Questions 3 and 4. Question 3 firstly asked if students worked in groups or individually or both and secondly, which they preferred. At all three survey dates (P1, $\mathrm{P} 2$, and $\mathrm{P} 3)$, students preferred working in groups ( $74 \%, 62 \%$, and $56 \%$, respectively-not shown), although the percentages from P1 to P3 show a decrease in this preference. Those preferring to work individually increased from $15 \%$ in $\mathrm{P} 1$ to $19 \%$ in P2 and $28 \%$ at the last survey date (not shown). Perhaps this shows that due to the pressure of time towards the end of the semester, the students rather completed their tasks alone or that they had become familiar with the methods used in the problem-based learning and preferred to work alone. Students who preferred both also showed an increase up to $15 \%$ in $\mathrm{P} 2$ and $16 \%$ in P3 from a mere $7 \%$ 
TABLE 1: Analysis of questionnaires for "Yes/No" answers for P1, P2, and P3 (P1 = 1st survey date; P2 = 2nd survey date; and P3 = 3rd survey date).

\begin{tabular}{|c|c|c|c|c|c|c|c|c|c|c|}
\hline \multirow[b]{2}{*}{ Question no. } & \multirow[b]{2}{*}{ Question } & \multicolumn{3}{|c|}{$\mathrm{P} 1(n=27)$} & \multicolumn{3}{|c|}{$\mathrm{P} 2(n=26)$} & \multicolumn{3}{|c|}{$\mathrm{P} 3(n=25)$} \\
\hline & & $\begin{array}{c}\text { Yes } \\
n(\%)\end{array}$ & $\begin{array}{c}\text { No } \\
n(\%)\end{array}$ & $\begin{array}{l}\text { None } \\
n(\%)\end{array}$ & $\begin{array}{c}\text { Yes } \\
n(\%)\end{array}$ & $\begin{array}{c}\text { No } \\
n(\%)\end{array}$ & $\begin{array}{l}\text { None } \\
n(\%)\end{array}$ & $\begin{array}{c}\text { Yes } \\
n(\%)\end{array}$ & $\begin{array}{c}\text { No } \\
n(\%)\end{array}$ & $\begin{array}{l}\text { None } \\
n(\%)\end{array}$ \\
\hline 1 & $\begin{array}{c}\text { Could you easily access the Excel data on } \\
\text { Blackboard? }\end{array}$ & $19(70)$ & $7(26)$ & $1(4)$ & $22(85)$ & $4(15)$ & - & $24(96)$ & $1(4)$ & - \\
\hline 2 & $\begin{array}{l}\text { Did you read the instructions for the } \\
\text { practical before you attempted to do it? }\end{array}$ & $27(100)$ & - & - & $26(100)$ & - & - & $23(92)$ & $1(4)$ & $1(4)$ \\
\hline 5 & $\begin{array}{l}\text { Do you feel that you benefited from the } \\
\text { practical? }\end{array}$ & $22(81)$ & $4(15)$ & $1(4)$ & $22(85)$ & $3(12)$ & $1(4)$ & $21(84)$ & $4(16)$ & - \\
\hline 6 & $\begin{array}{c}\text { Do you prefer this type of } \\
\text { (problem-based) practical to practicals } \\
\text { which are not problem based? }\end{array}$ & $21(78)$ & $5(19)$ & $1(4)$ & $14(54)$ & $10(38)$ & $2(8)$ & $18(72)$ & $6(24)$ & $1(4)$ \\
\hline 7 & $\begin{array}{l}\text { Do you think the practical has improved } \\
\text { your knowledge and better prepared you } \\
\text { for the workplace? }\end{array}$ & $23(85)$ & $4(15)$ & - & $20(77)$ & $5(19)$ & $1(4)$ & $23(92)$ & $2(8)$ & - \\
\hline 8 & $\begin{array}{l}\text { Do you have recommendations for } \\
\text { improving the practical? }\end{array}$ & $11(41)$ & $8(30)$ & $8(30)$ & $13(50)$ & $6(23)$ & $7(27)$ & $14(56)$ & $5(20)$ & $6(24)$ \\
\hline
\end{tabular}

in P1. It seems that the students formed working groups during the first half of the semester and then some of them left these groups as the semester progressed. These students obviously learnt independently as well as from others in their groups. This phenomenon is in agreement with other literature sources such as that by Benedict [7], who reported in an advanced therapeutic study that the medical students had learnt independently as well as from each other.

Table 2 represents a summary of the comments from all three survey dates, and the results overall indicate that students were generally very positive about this problembased module. The results in Table 2 were very difficult to analyse because the students express themselves differently resulting in many different answers, but an effort was made to group similar comments together; for example, in question 3 , students gave their comments about why they preferred to work on their own or individually, in a group or both.

At all three survey dates (P1, P2, and P3) the term "less confusion" was coined for comments such as the following.

(i) I like to be certain.

(ii) More can be achieved (students most probably mean they can concentrate better when they are not confused).

(iii) I understand the work better.

(iv) I get less confused.

(v) Mistakes can be more easily corrected.

(vi) I like to solve problems.

(vii) I know what I know.

Another reason for preferring to work alone was that there was less conflict. This comment was given in P2 and P3 but did not occur in P1, probably because this may have been the first time students had worked in groups in a science subject and some found that it had not really worked for them (because of possible conflict). Students who preferred working in groups (Table 2) said that their understanding had much improved with number of students stating this type of answer equal to 12,8 , and 8 in $\mathrm{P} 1, \mathrm{P} 2$, and $\mathrm{P} 3$, respectively. This is in accordance with statements made by Rust [9] who stated that one should remember that research evidence indicates that students need to actively participate in classes in some way (such as in a group format) to be able to understand what is being taught. Kelly and Finlayson [2] stated that a combination of group work, discussions, and hands-on activities allowed students to develop their understanding through deep learning. Students who preferred working both individually and in groups numbered 3 for P1 and P2 and 4 for $\mathrm{P} 3$, the reason being that they liked the interaction with the other students, as then they could receive input and/or help from the group as well as give their own input, but still do the practicum on their own. It is assumed that they may have worked in groups during the initial stages of an exercise then alone during the final write-up for submission. Alternatively, perhaps they initially worked alone but struggled too much, so they reverted to group work to solve the problem and do the analysis. To be able to distinguish between these alternatives one would have to either interview the students or provide more detailed questions at a later stage, so it is not possible to decipher now.

Question 4 asked what the most important thing/lesson learnt was, and students mostly acknowledged that they had acquired a knowledge of the weather with 9, 4, and 0 students giving this comment in P1, P2, and P3, respectively. During each of the questionnaire opportunities, however, students appreciated that they did learn the spreadsheet package Excel $(6,2,1$, resp.), and in P2 and P3, three students in each said they had learnt how to think critically. Presumably, these skills will be transferable and will stand them in good stead 
in future. It is very encouraging to know that they could even acknowledge that they learnt it in this agrometeorology class. A study conducted by Kumar and Kogut [19] stated that the goal of learning is to encourage students to be reflective critical thinkers. Masek and Yamin [22] also state that various studies show positive results relating problembased learning and critical thinking, although their own study did not show significant differences between problembased and conventional learning. In this study students were required to give their feedback on problem-based learning, and some of the comments were that the students felt they had become more independent as they learnt to think, rather than being "spoon-fed."

3.3. Answers to Questions 5 and 6. Question 5 asked whether and in what way the students had benefited from the exercises in the practicums. Table 2 shows that the students who answered in the affirmative mostly said that they had accumulated knowledge and learnt applicability or skills (practical application possible) in the sphere of weather and climate. Some also said their understanding of weather- and climaterelated matters had improved. Students who answered in the negative said that they did not understand the practicums (P1 and P3) or that the practicums were too difficult or that there were too many (P2). One student in P1 also said that the practicums were not applicable to him/her, so one wonders why that student was taking this module. Students could have accumulated knowledge by other means/methods of teaching such as through rote learning; however, deep learning and understanding and being able to apply the things learnt to other situations is seldom learnt by "rote" or memorization or by repetition. According to Kumar and Kogut [19] student feedback suggested that students preferred problem-based learning to rote learning as the latter meant having to sit through long exam sessions answering questions from memory rather than making their own inferences. Hilgard et al. [23] also found that students who learn with understanding are able to transfer their knowledge to tasks requiring problem-solving with greater success than those who learn only by rote.

Question 6 asked students about their preferences in learning methods comparing problem based practicum exercises to those which were not problem based. Table 1 clearly shows that the majority preferred the problem-based practicum exercises, and it would be reasonable to assume that they are not just trying to appease the lecturer but are giving an honest answer. Reasons given were that their critical thinking was stimulated (Table 2); applicability or skills were learnt, and understanding was positively reenforced. These answers were recorded at all three survey dates through the semester. Students who answered in the negative said that the work was difficult $(1,3$, and 4 in $\mathrm{P} 1, \mathrm{P} 2$, and $\mathrm{P} 3$, resp.), while others said they had no reason (2 and 4 in P1 and P2, resp.) or that it was confusing for them (2 in P2). So if it was confusing, this provides an opportunity for the lecturing staff to work on improving the introduction and explanation of the specific exercises and how to approach them. If the problem originates with the student, then maybe it is because the student does not remember/recall the information from introductory classes on agrometeorology which they took the previous year.

3.4. Answers to Questions 7 and 8. Question 7 asked whether the students thought the practicums had improved their knowledge and better prepared them for the workplace and why. Students answering in the affirmative said they were confident that they were prepared for the workplace (5 in $\mathrm{P} 1,0$ in $\mathrm{P} 2$, and 6 in P3), and one would hope that this was due at least in part to the learning method; others, namely, 2,5 , and 2 (P1, P2, and P3, resp.), felt they had accumulated knowledge, which could probably have been achieved with other learning methods also. Some other reasons were also given, such as that their critical thinking had improved and that they had learnt how to apply what they were learning to real-life problems as well as new skills. Students answering this question in the negative said they did not understand the practicums ( 2 at each survey date). The possibility always exists that some students did not understand the practicums or that they missed the introductory lecture class or did not have the correct background to understand some of the technical terms. During this semester the lecturers were (and are always) willing to help them, but often there is no indication that there are students who do not follow. One can then only assume that the students do not want to admit their ignorance (particularly in front of other students), either because they are too shy or because they did not concentrate during the explanation of the practicum.

Question 8 asked if there were any recommendations for improving the practicum exercises. The majority of the students gave recommendations for improvements, but differences between the remainder who said no and those who did not comment was quite small; that is, in P1 eight students said no and 8 students did not answer. In P2 six students said no and 7 did not answer. In P3 six students said no and 6 did not answer (Tables 1 and 2). So it seems as though either these students did not want to apply their mind to this side of the class and how it could be improved or that they were pushed for time when completing the survey and could not bother to think about alternatives or other applications or things that they would see as problems that could be developed into learning modules. Some of the recommendations from the majority of students were as follows (Table 2).

(i) More tutors (2 in P1 and 1 in P3).

(ii) More patient lecturers (1 in P1 and 1 in P3).

(iii) Preparation before practicums (2, 2, and 2, resp.).

(iv) Memorandums to be given and discussed (2 each in $\mathrm{P} 1$ and $\mathrm{P} 2)$.

(v) More examples to be given (4 and 8 in P2 and P3).

Some of these recommendations need to be addressed before the class is presented next year. For instance, more tutors in the computer lab is really something that needs attention as has been stated, the number of students in this class had rapidly increased over the past few years, and perhaps 
TABLE 2: Summary of main comments, according to question number on questionnaire given to LWR314 students at all three survey dates (P1, P2, and P3) (Number of students who made comments on P1, P2, and P3, respectively, given in brackets under comments).

\begin{tabular}{|c|c|c|}
\hline Question no. & Question & Comments \\
\hline 3 & $\begin{array}{l}\text { Do you prefer to work in a group or individually } \\
\text { or both? Why? }\end{array}$ & $\begin{array}{l}\text { Individually-less confusion }(3,3,3) \text { and less conflict }(0,3,3) \text {. } \\
\text { Group-understanding improved }(12,8,8) \text {. } \\
\text { Both-interaction aspect }(3,3,4) .\end{array}$ \\
\hline 4 & $\begin{array}{l}\text { What is the most important thing/lesson you have } \\
\text { learnt from this practical? }\end{array}$ & $\begin{array}{l}\text { How Excel works }(6,2,1) \\
\text { Knowledge of the weather }(9,4,0) \\
\text { Knowledge of drought }(0,0,4) \\
\text { Critical thinking }(0,3,3)\end{array}$ \\
\hline 5 & $\begin{array}{l}\text { Do you feel that you benefited from the practical? } \\
\text { How? }\end{array}$ & $\begin{array}{l}\text { Yes-Knowlege accumulation }(4,7,6) \text {; learnt applicability. } \\
\text { (skills/practical application possible) }(3,7,4) \text {; understanding } \\
\text { improved }(0,3,3) \text {. } \\
\text { No-No understanding }(2,0,2) \text {; not applicable }(1,0,0) \text {; programs } \\
\text { difficult }(0,1,0) \text {; too many practicals }(0,1,0) \text {. }\end{array}$ \\
\hline 6 & $\begin{array}{l}\text { Do you prefer this type of (problem-based) } \\
\text { practical to practicals which are not problem } \\
\text { based? Why? }\end{array}$ & $\begin{array}{l}\text { Yes-Critcal thinking }(5,3,2) \text {; learnt applicability/skills }(3,1,1) \text {; } \\
\text { reenforces understanding }(1,2,2) \text {. } \\
\text { No-It is difficult }(1,3,4) \text {; no reason }(2,4,0) \text {; confusing }(0,2,0) \text {. }\end{array}$ \\
\hline 7 & $\begin{array}{l}\text { Do you think the practical has improved your } \\
\text { knowledge and better prepared you for the } \\
\text { workplace? Why? }\end{array}$ & $\begin{array}{l}\text { Yes-Critical thinking }(2,1,3) \text {; prepares for workplace }(5,0,6) \text {; } \\
\text { knowledge accumulation }(2,5,2) \text {; learnt applicability/skills }(1,2,2) \text {. } \\
\text { No-No understanding }(2,2,2) \text {. }\end{array}$ \\
\hline 8 & $\begin{array}{l}\text { Do you have recommendations for improving the } \\
\text { practical? Give your reasons. }\end{array}$ & $\begin{array}{l}\text { Yes-More tutors }(2,0,1) \text {; more patient lecturers }(1,0,1) \text {; preparation } \\
\text { before practical }(2,2,2) \text {; memorandums }(2,2,0) \text {; more examples }(0 \text {, } \\
4,8) \text {. } \\
\text { No-No recommendations }(8,6,6) \text {. } \\
\text { None-No answer }(8,7,6) \text {. }\end{array}$ \\
\hline
\end{tabular}

lecturers had not given this enough thought and did not consider that the tutor-to-student ratio had now become quite low. This needs to be brought to the attention of the head of department, and it needs to be emphasised that in order to maintain the course in this "problem-based" learning style more tutors are necessary or the students become frustrated, as they must wait too long before receiving assistance during the 3-hour practicum class time. The recommendation about impatient lecturers may also be due to work overload and pressure during this time with over 35 students and only 2 people to help answer questions when each student is working on a computer as an individual. It is a little unclear what is meant by "more preparation before the practicum" - is this by the student or by the lecturer? Some students recommended that lecturers discuss and explain the practicum during the week before the practicum session (but actually the lecturer usually does this-so maybe it is due to poor class attendance) to help save them time during the practicum session itself. The last two comments are mainly due to the time pressure during each week for each topic with only $3 \times 1 \mathrm{~h}$ classes and 1 $\times 3 \mathrm{~h}$ practicum period-so no extra time is available for other examples or to go over the answer sheets/memorandum, only after the assignment has been graded and returned to the students.

There were several other recommendations made, both positive and negative, which were not repeated at all survey dates, for example, in P1: "Keep up the good work-we enjoy it"; or in contrast in P2: "Just cancel the practical-no good at all," and in P3: "Everything on hardcopy," and so forth. These recommendations were also taken note of as each student is entitled to his or her own opinion, but the latter comment is totally impractical (pages and pages of data) and would not be in line with keeping up to date, technologically speaking.

3.5. Comparison of Questions 3 and 6. According to the results of the comparison between questions 3 and 6 for the yes answers (Figure 2), the majority of students (59\%) in P1 chose group work as their preferred method of working in a problem-based learning environment. This was compared to $36 \%$ of students in P3 and to $31 \%$ of students in P2. In P3, 20\% of students said they preferred to work individually, but $16 \%$ of students from P3 and 15\% from P2 said they preferred both. These results, therefore, indicate that approximately onethird to two-thirds of the students who said they preferred problem-based practicums also said they preferred group work. This is very encouraging as one of the requirements for problem-based learning is that students work in groups, and students can really benefit if they are prepared to communicate with others. White (2002), as quoted by Kelly and Finlayson [2], stated that students would understand better what they learned and "remember longer by working cooperatively in groups,"

These group working skills would also be transferable to other situations that the students find themselves in outside the classroom. A minority of students $(<7 \%)$ did not respond (not shown) to the question at all three survey dates (P1, P2, and P3).

According to Figure 2 most of the students who said no to question 6 (did not prefer problem-based learning) showed 


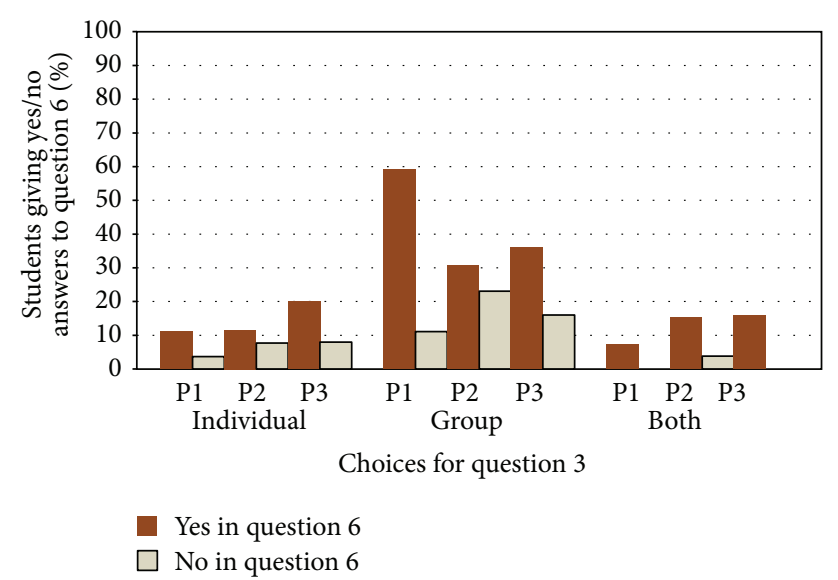

FIGURE 2: Comparison of results for questions 3 (do you prefer working in a group or individually or both?) and 6 (do you prefer problem-based practical or not?) for the questionnaire completed by third-year students at survey dates P1, P2, and P3.

$23 \%$ for group work in P2. In other words, these students enjoyed working in groups but did not prefer a problembased learning environment. This was compared to $16 \%$ students in P3 and 11\% of students in P1. All other results were $\leq 8 \%$, that is, very few students who did not prefer problembased learning but preferred to work individually, or both, or none. This implies that overall most of the students who did not prefer problem-based learning also preferred group work. Students therefore seemed to prefer the interaction with other students, even though they shied away from the problem-based type of teaching. The goal of the lecturers should be to try and narrow the gap between students who prefer problem-based learning and those who do not; that is, students should be taught how to think-in this way more students will come to prefer solving problems, as opposed to being spoon-fed. Students who do not prefer problembased learning most likely are not very successful in this area, and this needs to be taken into account by lecturers by encouraging students to participate in problem-based learning, so that learning outcomes can be optimal [19].

3.6. Statistical Analysis. Results from the ANOVA analysis performed on the answers in Table 1 (questions 1, 2, 5, 6, 7 , and 8) to test for significant differences in percentages between the survey dates (P1, P2, and P3) showed that all $P$ values $>0.05$. The values were: (a) 0.78 for "yes," (b) 0.20 for "no," and (c) 1.00 for "none", which means that the null hypothesis is accepted, and so this indicates that there were no significant differences between survey dates. This seems to show that there was no or very little change in student opinions throughout the semester and that what they believed in the beginning of the semester continues through to the end of the course. This points to relative consistency in the percentages between the survey dates; for example, question 5 asked whether students felt they had benefited from the practicums, resulting in $81 \%, 85 \%$, and $84 \%$ "yes" answers, which is stable through the semester. There would be a serious problem had the percentages been very different (and hence statistically significant) because then one would have to further investigate the cause of the inconsistency and whether it was due to student or lecturer error or oversight. Even though the outcome for the ANOVA analysis was statistically insignificant, the results are by no means unimportant [24].

\section{Conclusions}

The objective of the study to investigate how students felt about learning through problem-based learning has been achieved. The study showed that the overwhelming majority of students in the 2011 LWR314 class were in favour of problem-based learning, which is based on making applications of theory into practical situations. The main reason students gave for preferring to work in groups was that their understanding had improved. Students who preferred to work on their own felt there was less confusion and conflict, and those who preferred both enjoyed the interaction that groups provided as well as being able to formulate their own individual ideas. Students benefited from problembased learning in that they improved their knowledge, skills, and critical thinking abilities and felt that they had learnt something that could benefit them throughout their future lives out in the world and the workplace. The lecturing staff at agrometeorology (UFS) are determined to give each student the best assistance and guidance possible and to improve the problem-based module LWR314 where necessary, taking into consideration the comments and results collected in this study. Case studies such as this one prove the importance of allowing students to develop their critical thinking skills. These skills will remain with them even after they have left the university environment.

\section{Acknowledgments}

The study was presented at the CALMet IX conference in Pretoria from 3 to 8 October 2011. The authors would like to acknowledge Liesl van der Westhuizen (University of the Free State) for assistance with the survey as well as editing of the paper. S. Walker is the research theme leader for crop physiology, agroclimatology, and agroecological potential and programme director of CropBase, CFFRC.

\section{References}

[1] M. Motah, "Learning, types of learning, traditional learning styles and the impact of e-learning on the performance of secondary school students: the perceptions of teachers," in Proceedings of the Computer Science and IT Education Conference, University of Technology, Mauritius, India, November 2007.

[2] O. C. Kelly and O. E. Finlayson, "Providing solutions through problem-based learning for the undergraduate 1st year chemistry laboratory," Chemistry Education Research and Practice, vol. 8, no. 3, pp. 347-361, 2007.

[3] C. Kendal-Wright and R. Kasuya, "Team based learning: a potential addition to the JABSOM curriculum," Hawaii Medical Journal, vol. 69, no. 10, pp. 247-248, 2010. 
[4] F. Forsythe, "Problem-based Learning," in The Handbook For Economics Lecturers, P. Davies, Ed., University of Staffordshire, http://www.economicsnetwork.ac.uk/handbook/printable/pbl_ v5.pdf.

[5] M. Karakas, "Graduating reflective science teachers through problem based learning instruction," Bulgarian Journal of Science and Education Policy, vol. 2, no. 1, pp. 59-71, 2008.

[6] F. Dochy, M. Segers, P. V. D. Bossche, and K. Struyven, "Students' perceptions of a problem-based learning environment," Learning Environments Research, vol. 8, no. 1, pp. 41-66, 2005.

[7] N. Benedict, "Teachers' topics. Virtual patients and problembased learning in advanced therapeutics," The American Journal of Pharmaceutical Education, vol. 74, no. 8, article 143, pp. 1-5, 2010.

[8] K. Strohfeldt and D. T. Grant, "A model for self-directed problem-based learning for renal therapeutics," The American Journal of Pharmaceutical Education, vol. 74, no. 9, article 173, pp. 1-7, 2010.

[9] C. Rust, "The impact of assessment on student learning," Active Learning in Higher Education, vol. 3, no. 2, pp. 145-158, 2002.

[10] J. Biggs, Teaching for Quality Learning at University, Open University Press, Buckingham, UK, 2nd edition, 2003.

[11] K. Greasley and P. Ashworth, "The phenomenology of approach to studying: the university student's studies within the lifeworld," British Educational Research Journal, vol. 33, no. 6, pp. 819-843, 2007.

[12] J. T. E. Richardson, "The role of response biases in the relationship between students'perceptions of their courses and their approaches to studying in higher education," British Educational Research Journal, vol. 38, no. 3, pp. 399-418, 2012.

[13] M. M. Zingone, A. S. Franks, A. B. Guirguis, C. M. George, A. Howard-Thompson, and R. E. Heidel, "Comparing teambased and mixed active-learning methods in an ambulatory care elective course," The American Journal of Pharmaceutical Education, vol. 74, no. 9, article 160, pp. 1-7, 2010.

[14] Faculty of Natural and Agricultural Sciences, Yearbook 2011. Part 4: Agricultural Sciences: Undergraduate Programmes, University of the Free State, Bloemfontein, South Africa, 2011, http://natagri.ufs.ac.za/templates/yearbook.aspx .

[15] J. Lomas, J. Collins, S. Gachara, and S. Mukhopadhyay, "Education and training in Agrometeorology," CAgM Report 78, WMO/TD No. 990, Geneva Switzerland, 2000, http://www .wmo.int/pages/prog/wcp/agm/publications/cagm_reports.php.

[16] J. Lomas, J. R. Milford, and E. Mukhala, "Education and training in agricultural meteorology: current status and future needs," Agricultural and Forest Meteorology, vol. 103, no. 1-2, pp. 197208, 2000.

[17] K. Gregson, L. M. Romito, and L. P. Garetto, "Students' attitudes toward integrating problem-based learning into a D.D.S. Pharmacology curriculum," Journal of Dental Education, vol. 74, no. 5, pp. 489-498, 2010.

[18] S. J. Wright, "Student perceptions of an upper-level, undergraduate human anatomy Laboratory course without cadavers," Anatomy and Science Education, vol. 5, pp. 146-157, 2012.

[19] M. Kumar and G. Kogut, "Students'perceptions of problembased learning," Teacher Development, vol. 10, no. 1, pp. 105-116, 2006.

[20] E. R. Babbie, The Practice of Social Research, Wadsworth Publishing Company, Belmont, Mass, USA, 7th edition, 1995.

[21] J. Mouton, How To Succeed in Your Master's and docToral Studies, Van Schaik Publishers, Pretoria, South Africa, 7th edition, 2004.
[22] A. Masek and S. Yamin, "The impact of instructional methods on critical thinking: a comparison of problem-based learning and conventional approach in Engineering education," ISRN Education, vol. 2012, Article ID 759241, 6 pages, 2012.

[23] E. R. Hilgard, R. P. Irvine, and J. E. Whipple, "Rote memorization, understanding, and transfer: an extension of Katona's card-trick experiments," Journal of Experimental Psychology, vol. 46, no. 4, pp. 288-292, 1953.

[24] D. H. Robinson, L. O'Ryan, J. R. Levin, and D. HalburRamseyer, "Does statistical language constitute a "significant" roadblock to readers' interpretations of research results?" Journal of Educational Psychology, vol. 93, no. 3, pp. 646-654, 2001. 

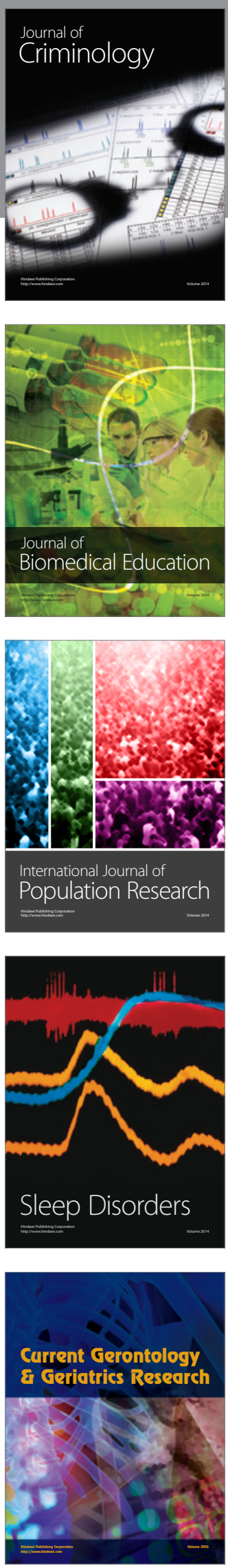
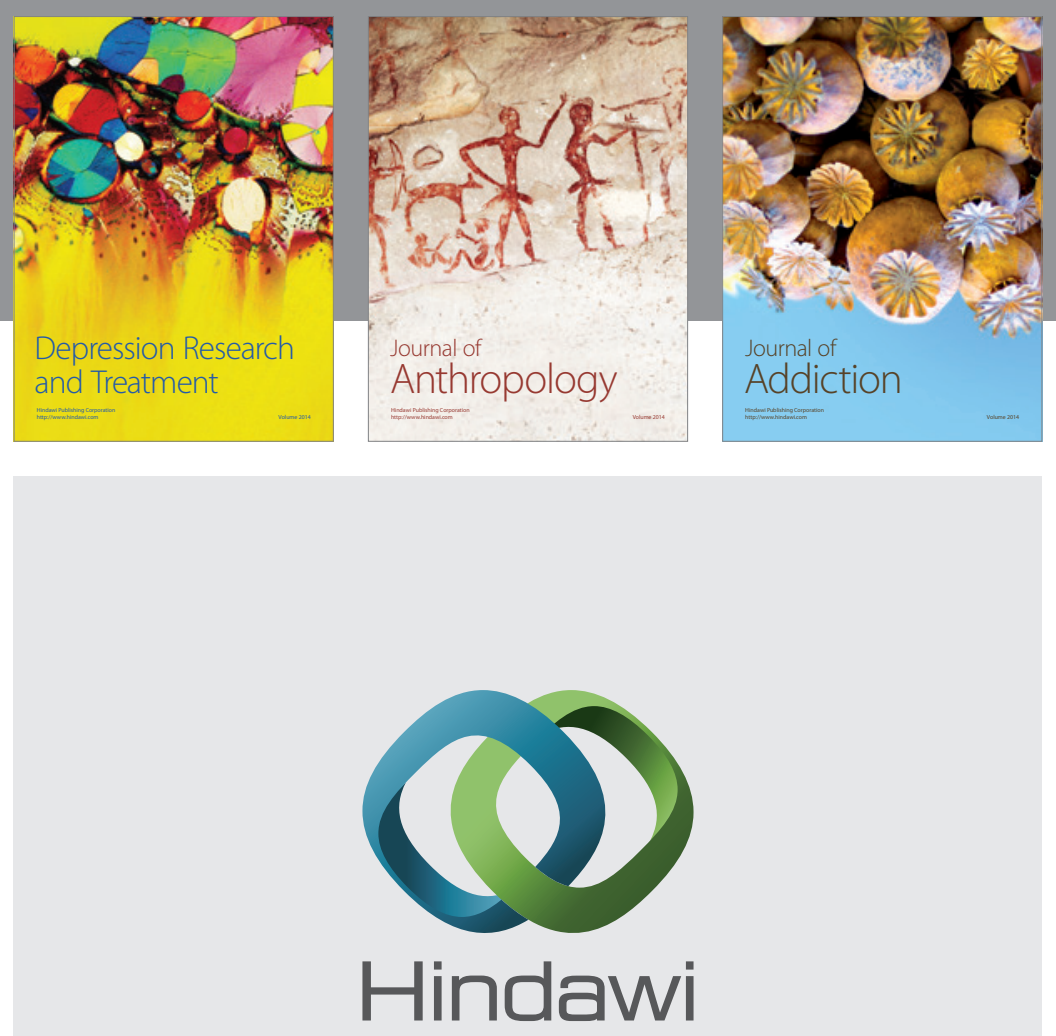

Submit your manuscripts at

http://www.hindawi.com

Child Development Research
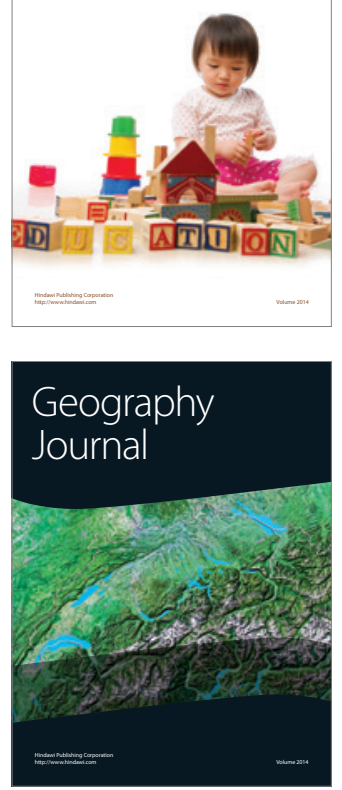

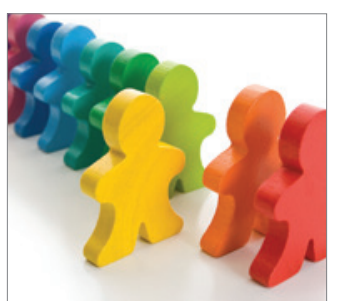

Autism

Research and Treatment
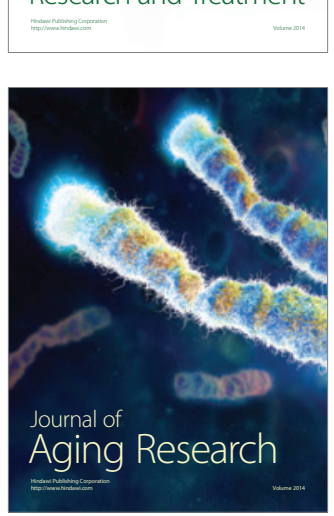
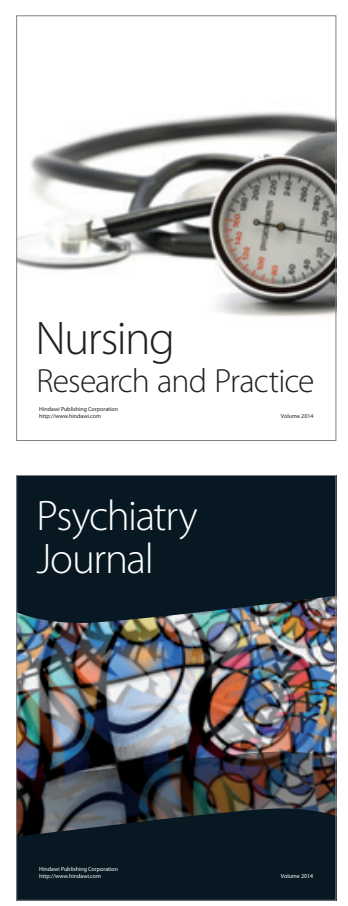
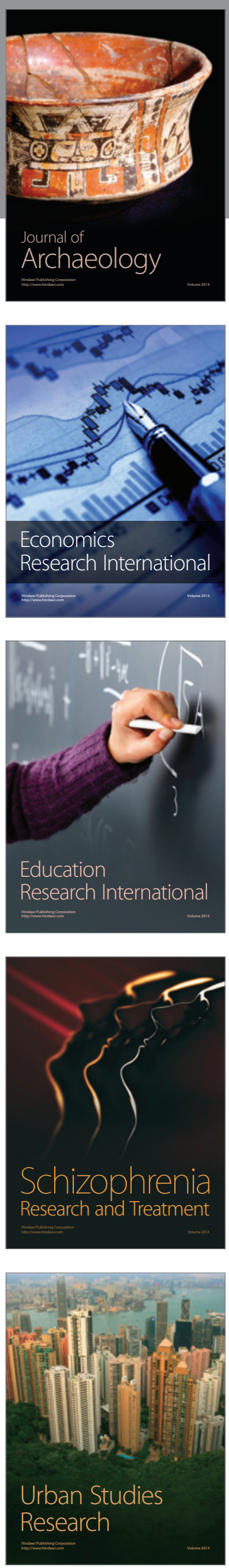